\title{
Implications of GMO cultivation and monitoring-series
}

\author{
Gunther Schmidt*, Winfried Schröder
}

Genetic engineering is a technological approach that allows for the application of new genetic material across species borders. It is assumed to yield specific benefits, e.g., increased food production, decreased use of pesticides and herbicides, and improved food quality. However, after more than a decade of commercial experience in some countries outside Europe, it seems apparent that several initial expectations could not be met, for example, the overall reduction in pesticide use. Unlike chemicals that degrade by time, genetically modified organisms (GMO) as well as their decomposition products have the potential to proliferate and persist in the environment, eventually without the possibility of removing them once they have been released. Thus, concerns have been raised about potential adverse environmental impacts of the GMO and about potential implications on the coexistence between conventional and genetically modified production. This makes risk assessment as well as monitoring highly challenging tasks towards minimising the risk of adverse effects. Ecological, agricultural and economic implications resulting from the cultivation of GMO at large spatial scales are currently discussed in science, administration and in the context of agricultural practice. A challenging task in this context is how to assess large-scale and long-term effects of GMO release in the approval procedure, in the planning of coexistence measures and in post-market monitoring regarding environmental as well as food monitoring. The international conference 'Implications of GM Crop Cultivation at Large Spatial Scales' (GMLS) was held at the University of Bremen first in April 2008. In March 2010, a second edition of the conference (GMLS II) was initiated. Presenters from 11 European and overseas nations contributed new scientific findings on risk analysis of GMO and largescale assessments of environmental effects. As it was for the first GMLS conference in 2008, the results were

\footnotetext{
* Correspondence: gschmidt@iuw.uni-vechta.de

University of Vechta, PO-Box 1553, 49364 Vechta, Germany
}

documented on the website http://www.gmls.eu. Topics include empirical work concerning findings on GM traits, dispersal of GMO, and possible effects on nontarget organisms as well as risk assessment, theoretical concepts and methodological aspects such as modelling and data analysis facing large spatial and temporal dimensions. Strategic implications for good governance and approaches for unknown effects have been discussed from a social-ecological perspective. GMLS is part of the studies on systemic risks funded by the $\mathrm{BMBF}^{\mathrm{a}}$ in the call on Social Ecological research. In this context, scientific findings are linked to social considerations on how nature and the human society mutually influence each other. This interdisciplinary approach aims at a deeper understanding of the following mutual response: How do social actions shape the environment, and, vice versa, how do environmental processes impact the success of social activities-agriculture as well as other natural resource uses.

This special series publishes some key contributions presented at the GMLS II conference. The articles describe different aspects of large-scale cultivation of GMOs:

Overview of the series, thematically oriented:

1. A case study of GM maize gene flow in South African Chris Viljoen, Lukeshni Chetty

2. Setup, efforts and significance of a GMO monitoring program - An Austrian case study Kathrin Pascher, Dietmar Moser, Stefan Dullinger, Leopold Sachslehner, Patrick Gros, Norbert Sauberer, Andreas Traxler, Georg Grabherr, Thomas Frank 3. A modeling assessment of geneflow in smallholder agriculture in West Africa Denis Worlanyo Aheto, Hauke Reuter, Broder Breckling

4. Monitoring of Bt-maize in Germany by means of Open Source based WebGIS Lukas Kleppin, Gunther Schmidt, Winfried Schröder

5. Environmental Risk Assessment of Genetically Modified Plants - Concepts and Controversies 
Angelika, Hilbeck, Matthias Meier, Jörg Römbke, Stephan Jänsch, Hanka Teichmann, Beatrix Tappeser 6. Genetically modified crops safety assessments: present limits and possible improvements. GillesEric Séralini, Robin Mesnage, Emilie Clair, Steeve Gress, Joël Spiroux de Vendômois, Dominique Cellier

7. From risk assessment to in-context trajectory evaluation: GMOs and their social implications Vincenzo Pavone, Joanna Goven, Riccardo Guarino 8. Systemic risks of genetically modified crops: the need for new approaches to risk assessment Hartmut Meyer

$$
\text { to be continued }
$$

The conference emphasised the necessity of independent and publicly accessible research results for GMO investigations. The conference illustrated that GMO risk assessment can build on relevant information, e.g. referring to biochemical characterisation, physiological and agronomic studies. However, considerable gaps exist in the assessment of biodiversity effects, and how non-target organisms would be impacted by GM crop cultivation. Landscape and regional studies are even scarcer. Uncertainties and the possibility to come up with much more reliable test results exist also with regard to human health aspects. Considerable scientific work has to be done to solve the remaining open questions.

\section{Endnotes}

${ }^{a}$ Federal Ministry of Education and Research

Received: 24 January 2011 Accepted: 2 February 2011

Published: 2 February 2011

doi:10.1186/2190-4715-23-2

Cite this article as: Schmidt and Schröder: Implications of GMO

cultivation and monitoring-series. Environmental Sciences Europe 2011 23:2.

\section{Submit your manuscript to a SpringerOpen ${ }^{\mathcal{D}}$ journal and benefit from:}

- Convenient online submission

- Rigorous peer review

- Immediate publication on acceptance

- Open access: articles freely available online

- High visibility within the field

- Retaining the copyright to your article

Submit your next manuscript at $\gg$ springeropen.com 